\title{
TECHNOLOGY AND EQUIPMENT FOR ION CHEMICAL-HEAT TREATMENT OF AGRICULTURAL MACHINERY PARTS
}

Mihail Bosyakov, Sergej Bondarenko, Aleksandr Bondarenko, Anton Maiseyenka

Physics and Technology Institute of National Academy of Sciences of Belarus, Belarus plasma.by.metal@gmail.com, bonds@inbox.ru,sashka3001@gmail.com, maiseyenka.a.n@gmail.com

\begin{abstract}
The paper describes a method for controlling the process of ion nitriding on industrial equipment based on the formation of a flux of molecular nitrogen ions in a glow discharge, the value of which is consistent with the absorptive capacity of steel, depending on its chemical composition and nitriding temperature. This method was developed at the Physical-Technical Institute NAS of Belarus and is successfully used by the largest machine-building enterprises of Belarus, in particular, OJSC "GOMSELMASH", for processing a wide range of parts from $16 \mathrm{MnCrS5}, 42 \mathrm{CMo} 4,41 \mathrm{CrAlMo} 7$ and others. Using this method of organization and the process of ion nitriding allows to obtain reproducible results of processing, regardless of the degree of loading of the camera with parts.
\end{abstract}

Keywords: plasma nitriding, current density, flux molecular ions of $\mathrm{N} 2+$.

\section{Introduction}

Heat treatment technology in agricultural engineering is constantly developing and improving. In the 80-ies of the XX century nitrocarburizing, three-dimensional and high frequency quenching methods were usually applied for gears and crankshafts made of steel 20X, 40ХГФ, 45 [1]. Nowadays, the method of plasma nitriding is widely used as a method of low-temperature chemical heat treatment of machine parts [2-4].

This is facilitated both by creation of high-tech automated ion nitriding equipment and improvement of the ion nitriding technology. The use of this technology allows: to reduce the process time (compared to gas nitriding), eliminate the fragility of the layer, increase contact endurance and ensure stability of the properties obtained for different types of parts.

In Belarus, the leader in the use of ion nitriding technology is undoubtedly OJSC "GOMSELMASH", which operates three plasma nitriding installations made in Belarus. The size of the working space of the chambers: No. 1 diameter-950, height-1200, No. 2 diameter-950, height2200, No. 3 diameter 1400, height-2000 (mm).

A distinctive feature of the operation of ion nitriding installations in large enterprises is the need for processing a sufficiently large variety of products. For example, OJSC "GOMSELMASH" uses plasma nitriding to process parts of grain and forage harvesters: shafts, floats, hubs, gears and other parts made of $16 \mathrm{MnCrS5}, 18 \mathrm{XГT,} 25 \mathrm{XГCA}, 42 \mathrm{CMo} 4,41 \mathrm{CrAlMo} 7$ steel. The temperature range of the ion nitriding process ranges from $480^{\circ} \mathrm{C}$ to $580^{\circ} \mathrm{C}$, depending on the grade of the steel and the temperature of the previous heat treatment. The depth of the hardened layer varies from 0.35 to 0.6 $\mathrm{mm}$.

The process temperature, saturation duration, pressure, composition and flow rate of the working gas mixture are the technological factors affecting the efficiency of plasma nitriding. In this case, the technology must provide reproducible results regardless of the configuration of the chamber. It should also be possible to combine parts of different geometry, mass and grades of steels in one load.

The first requirement is provided by the theoretical calculation of the nitrogen flux absorbed by the steel in accordance with its chemical composition. The second requirement is provided by use of special rigging.

The aim of this work is consideration of the effectiveness of the technology of plasma nitriding, developed in the PHTI NAS of Belarus, for example, nitriding of parts made of the following grades of steel: $16 \mathrm{MnCrS} 5,42 \mathrm{CMo} 4,41 \mathrm{CrAlMo} 7$.

\section{Technology of ion chemical and thermal treatment of parts}

From [5] it is known that the nitrogen flow absorbed by steel during the period of time, can be expressed by the following equation 


$$
\Pi_{N 2}=\frac{\sqrt{\pi}}{2} \times C_{\alpha F e} \times \sqrt{\frac{D_{\alpha F e}}{\tau}}, 1 \cdot\left(\mathrm{m}^{2} \cdot \mathrm{h}\right)^{-1}
$$

where $C_{\alpha-F e}$ - the solubility of $\mathrm{N}_{2}$ in $\alpha$-Fe steel, $\mathrm{g} \cdot \mathrm{m}^{-3}$;

$D_{\alpha-F e}-$ diffusion coefficient $\mathrm{N}_{2}$ in $\alpha-\mathrm{Fe}$ steel, $\mathrm{m}^{2} \cdot \mathrm{h}^{-1}$;

$\tau$ - time (s).

The values of $C_{\alpha-F e}$ and $D_{\alpha-F e}$ depend on both the chemical composition of the steel and the temperature of treatment [6]:

$$
C_{\alpha-\mathrm{Fe}}=\exp \left(\frac{-4575}{T}+3\right) \times 10^{-\left(K_{i}^{\left(n_{i}\right)} \ldots+K_{n}^{\left(n_{i}\right)}\right)},(\text { wt } \%)
$$

where: $K_{i}^{\left(n_{i}\right)}$ - activity coefficient of alloying element;

$T$ - temperature, $\mathrm{K}$.

$$
D_{\alpha-\mathrm{Fe}}=D_{0} \times \exp \left[\frac{B_{i}^{\left(n_{i}\right)}+\ldots+B_{n}^{\left(n_{n}\right)}}{T}\right],\left(\mathrm{m}^{2} \cdot \mathrm{s}^{-1}\right)
$$

where $B_{i}^{\left(n_{i}\right)}$-activity coefficient of alloying element;

$D_{0}$ - diffusion coefficient in ARMCO-Fe;

$T$ - temperature, $\mathrm{K}$.

Thus, using the equations (1-3) it is possible to estimate the nitrogen flow absorbed by the steel at the selected isothermal holding temperature and saturation time, "Fig. 1".

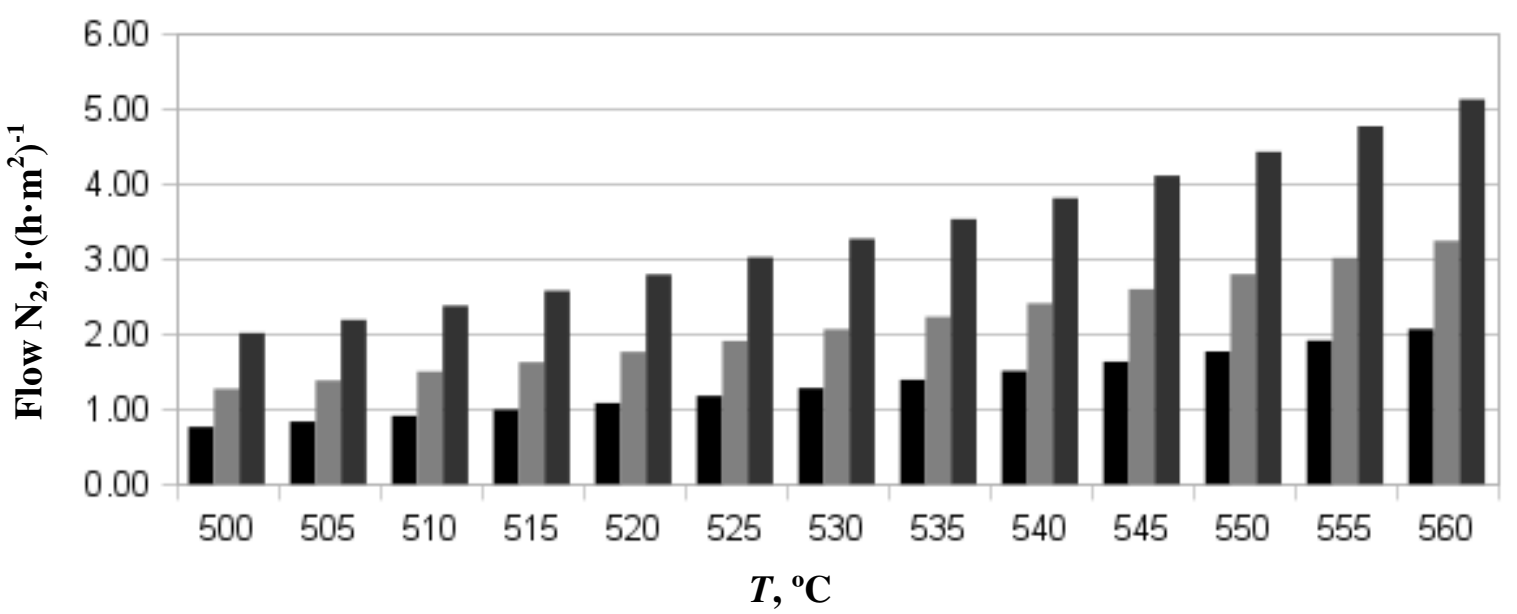

$41 \mathrm{CrAlMo} 7=41 \mathrm{Cr} 4=16 \mathrm{MnCrS5}$

Fig. 1. Flow of nitrogen absorbed by steel 41CrAlMo7, 41Cr4, 16MnCrS5 in temperature range $500-560{ }^{\circ} \mathrm{C}$

Based on the results of the calculation of the nitrogen flow absorbed by the steel, it is possible to predict the possibility of joint treatment of different steel grades. For example, from the data presented in Fig 1, steel $41 \mathrm{Cr} 4$ and $41 \mathrm{CrAlMo} 7$ can be processed together, but the steel $16 \mathrm{MnCrS} 5$ must be processed separately.

The nitrogen flow absorbed by steel is provided by a glow discharge by means of two mechanisms: dissociative recombination of molecular nitrogen ions on the surface of the cathode and dissociation of molecular nitrogen in the zone of negative glow of the cathode layer [8]. It should be noted that the discharge current density plays a key role in formation of the flux of active nitrogen for both mechanisms. According to [7], the discharge current density determines the flow of molecular 
nitrogen ions $\left(\mathrm{N}_{2}^{+}\right)$. Ions move to the cathode surface, where they dissociate into nitrogen atoms. This flow can be calculated using an equation:

$$
\Pi_{N_{2}^{+.}}=0.897 \times\left(\frac{I}{S}\right) \times\left(\frac{\% \mathrm{~N}_{2}}{100}\right), 1 \cdot\left(\mathrm{m}^{2} \cdot \mathrm{h}\right)^{-1}
$$

where 0.897 - coefficient of proportionality;

$I$ - discharge current, A;

$S$ - area of the cathode, $\mathrm{m}^{2}$;

$\% \mathrm{~N}_{2}$ - percentage of nitrogen in the gas mixture.

The interrelation of these parameters is reflected in [8], where the influence of the flux of molecular ions $\mathrm{N}_{2}{ }^{+}$on the absorption efficiency of $\mathrm{N}_{2}$ steel was studied by DIN 1.0978 (C -0.072 ; $\mathrm{Si}-0.1 ; \mathrm{Mn}-0.43 ; \mathrm{Cr}-0.041 ; \mathrm{Mo}-0.003 ; \mathrm{Ni}-0.04 ; \mathrm{Al}-0.034 ; \mathrm{Ti}-0.007 ; \mathrm{V}-0.003)$, Fig. 2.
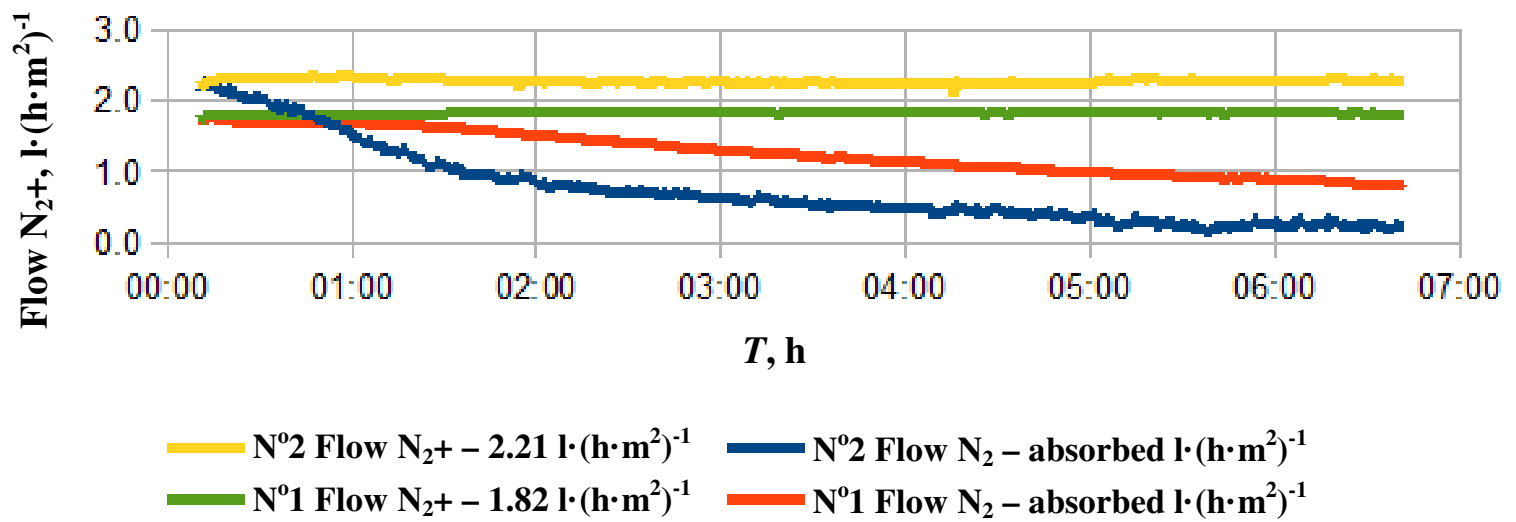

Fig. 2. Influence of flow of molecular ions $\mathbf{N}_{2}{ }^{+}$formed by discharge on absorption efficiency $\mathbf{N}_{2}$ during nitriding steel DIN 1,0978 at temperature $T-540{ }^{\circ} \mathrm{C}$

As it can be seen from the data in Fig 2, at the initial time nitrogen absorption by the steel coincides with the flow of $\mathrm{N}_{2}{ }^{+}$ions. Then the absorption $\mathrm{N}_{2}{ }^{+}$gradually decreases according to equation (1).

Therefore, for carrying out plasma nitriding it is necessary to consider both the current density and the chemical composition of the steel.

\section{Equipment for ion chemical and thermal treatment of parts}

Structurally, the equipment for ion nitriding consists of: working chamber, power supply system, gas vacuum system and cooling system. At the moment, the world uses conditionally two types of chambers for ion nitriding: passive hot-wall chamber Ionitech (Bulgaria) [9], PHTI (Belarus) [10], Puls-Plasma nitriding Units (Brazil) [11] and active hot-wall chamber PVA Industrial Vacuum Systems GmbH (Plateg) [12] (Germany), ELTROPULS Heat-Treatment-Unit [13] (Germany), RÜBIG Heat Treatment [14] (Austria).

However, a common condition for all types of equipment is the presence of abnormal glow discharge.

Abnormal glow discharge is a form of glow discharge, in which the entire area of the cathode is covered by a glow, and with an increase in the applied power, the discharge current increases along with the increase in voltage.

A normal glow discharge is a form of glow discharge, in which a part of the cathode is covered, and with an increase in the applied power, only the discharge current increases, while the magnitude of the cathode potential drop remains constant.

The first parameter, which allows classifying the glow discharge to normal and abnormal, is the value of the normal cathode potential drop. In the case of an iron cathode, this value is: $\mathrm{N}_{2}-215 \mathrm{~V}$, $\mathrm{H}_{2}-250 \mathrm{~V}$ and $\mathrm{Ar}-165 \mathrm{~V}$. 
The second parameter is the value $\mathrm{J} / \mathrm{p}^{2}$ the normal current density. In the case of an iron cathode, this value is: $\mathrm{N}_{2}-26 \cdot 10^{-6} \mathrm{~A} \cdot\left(\mathrm{m}^{2} \mathrm{~Pa}^{2}\right)^{-1}, \mathrm{H}_{2}-41 \cdot 10^{-6} \mathrm{~A} \cdot\left(\mathrm{m}^{2} \mathrm{~Pa}^{2}\right)^{-1}, \mathrm{Ar}-90 \cdot 10^{-6} \mathrm{~A} \cdot\left(\mathrm{m}^{2} \mathrm{~Pa}^{2}\right)^{-1}[15]$.

Consequently, if the value of the current density is less than the value of the normal current density for $\mathrm{N}_{2}$, which is the main component of the gas mixture, then the discharge will be absent on the part of the cathode.

The analysis of ion nitriding processes on industrial equipment shows that the range of the parameter $\mathrm{J} / \mathrm{p}^{2}$ is rather narrow and the value of the cathode potential drop is only 5-10\% higher than the value of the normal cathode potential drop for $\mathrm{N}_{2}$. Consequently, the current density, as well as the nitrogen content in the gas mixture, play a determining role in the formation of the chemical activity of the discharge. This is proved by the data of experiments given in [16; 17].

Control of the current density in the chambers with a passive hot wall, at a constant temperature of the cathode, is carried out by variation of the temperature of the chamber wall, thereby setting the power of thermal losses of the cathode and, accordingly, the discharge power.

The current density in the chambers with a passive hot wall depends on the temperature of the cathode and the number of heat shields and the degree of their blackness, [18], and the discharge current density can only be changed by changing the pressure in the chamber.

However, in cambers with passive hot walls, the heat loss capacity of the hatch can be stabilized by applying special rigging.

When plasma nitriding, the power released by the glow discharge on the cathode is determined by the current density and the magnitude of the cathode potential drop according to [15]

$$
W_{\text {heater }}=J \times U_{C p d},
$$

where $J$-current density, A $\cdot \mathrm{m}^{-2}$;

$U_{c p d}$ - magnitude of the cathode potential drop, $\mathrm{V}$, at that $U_{C p d}$ - is always less than the voltage applied to the cathode.

The power required to maintain the temperature of the cathode is determined by the heat exchange between the cathode and the chamber walls. Ballance equation:

$$
\Psi \times W_{\text {electric. }}=W_{\text {heater. }}=W_{\text {cooling. }},
$$

where $\Psi \approx 0.85$.

From [19] follows that if you take $W_{\text {cooling. }}=Q_{(c, c m .)}$, then the radiation from a cathode with a radiating area $F_{c}$ and the temperature $\mathrm{T}_{\mathrm{c}}$ to the wall having the temperature $\mathrm{T}_{\mathrm{w}}$ will look as:

$$
Q_{(c, c m)_{3}}=C_{0} \times A_{(c, c m)_{3}} \times F_{c} \times\left(\left[\frac{T_{c}}{100}\right]^{4}-\left[\frac{T_{w}}{100}\right]^{4}\right),
$$

where $A_{(c, c m)_{3}}$ - reduced absorption coefficient of the considered radiant system, having different meanings for the case of cylindrical screens and flat screens; $C_{0}$ - constant black solid radiation $5.67 \mathrm{~W} \cdot \mathrm{m}^{2} \cdot \mathrm{K}^{4}$.

As follows from the equation (7), the radiation flux depends on the temperature difference of the emitting solid (in this case - cathode) and the chamber wall (or screen), the area of the radiating surface and the reduced absorption coefficient as the cathode temperature increases, the heat flow to the wall increases, and its value is proportional to the emitting area $S_{\text {radiating }}$.

Thus, if you use a special rigging in the form of a cylinder of rolled steel, Fig. 3, the radiating surface of the hatch will be constant, hence the amount of power will be constant, regardless of the pressure in the chamber, as evidenced by the work data [19]. 


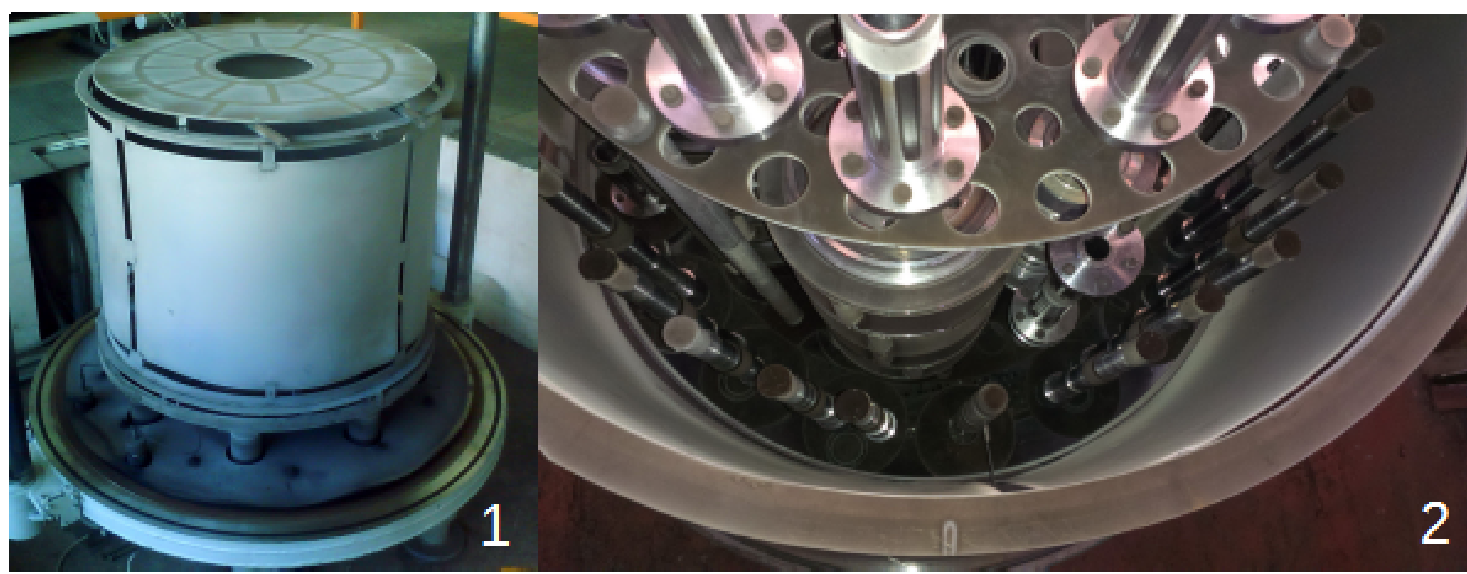

Fig. 3. Specialized rigging (1) for machining parts of different dimensions (2)

As the number of parts loaded inside the cylinder increases, the current density decreases. According to equation (4) it is necessary to increase the share of nitrogen in the gas mixture to compensate the decrease. Thus, it is possible to take into account in the calculations every additional part inside the cylinder and thus increase the density of the nitrogen stream according to the received area. This can be represented as a monogram, which shows the change in the flow rate of nitrogen and argon by increasing the number of parts in the chamber or the total area of the cathode, Fig. 4.

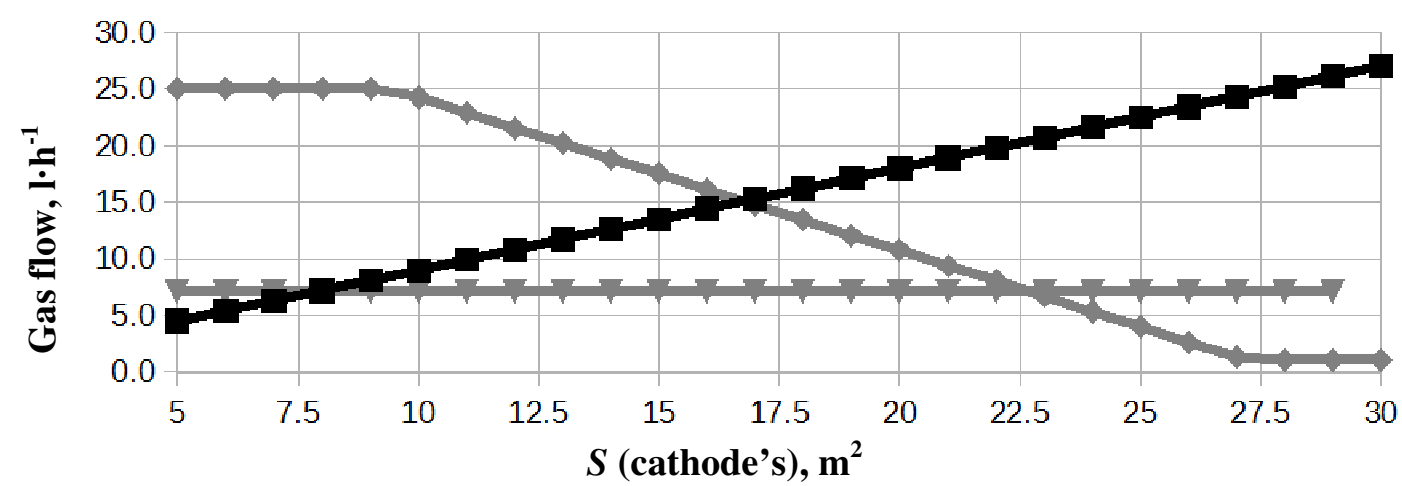

$$
-\mathrm{N}_{2}, \mathbf{l} \cdot \mathbf{h}^{-1}-A \mathbf{r}, \mathbf{l} \cdot \mathbf{h}^{-1}-\mathrm{H}_{2}, \mathbf{l} \cdot \mathbf{h}^{-1}
$$

Fig. 4. Flow rate of working gases depending on area of machined parts made of steel 16MnCrS5

The stability of the results is confirmed by numerous data, Table 1 .

Table 1

Results of ion nitriding parts made of steel $16 \mathrm{MnCrS5}\left(480^{\circ} \mathrm{C}, 18\right.$ hours $)$ at OJSC "GOMSELMASH"

\begin{tabular}{|c|c|c|c|}
\hline No. & $\boldsymbol{S}$ (parts), $\mathbf{~}^{\mathbf{2}}$ & $\begin{array}{c}\text { Depth of nitrided } \\
\text { layer, } \mathbf{~ m m}\end{array}$ & $\begin{array}{c}\text { Hardness at the } \\
\text { surface, HV } \mathbf{~ 0 . 1}\end{array}$ \\
\hline 1 & 3.88 & 0.41 & 693 \\
\hline 2 & 6.77 & 0.43 & 743 \\
\hline 3 & 8.14 & 0.41 & 730 \\
\hline 4 & 8.38 & 0.44 & 705 \\
\hline 5 & 8.95 & 0.42 & 693 \\
\hline 6 & 10.09 & 0.47 & 757 \\
\hline 7 & 10.68 & 0.41 & 705 \\
\hline 8 & 12.86 & 0.36 & 743 \\
\hline 9 & 13.42 & 0.36 & 730 \\
\hline 10 & 14.18 & 0.36 & 756 \\
\hline 11 & 16.34 & 0.42 & 757 \\
\hline
\end{tabular}


Thus, the main advantage of the ion nitriding technology developed in the FTI NAS of Belarus is its scalability - i.e. the technological parameters of the process are selected based on the geometry of the working chamber, the steel grade, the total area of the parts loaded inside the cylinder, and the nitriding temperature. This ensures the stability of the technology regardless of the loading the chamber.

\section{Conclusions}

1. Using the equations (1-3) it is possible to estimate the nitrogen flow absorbed by steel at the selected isothermal holding temperature and saturation time, which makes it possible to predict the possibility of joint treatment of different grades of steel.

2. During the plasma nitriding process it is necessary to take into account both the discharge current density and the chemical composition of the steel. Using equations (1-3) and equation( 4), reflecting the dependence of the flow $\mathrm{N}_{2}{ }^{+}$on the current density and the share of $\mathrm{N}_{2}$ gas mixture, you can calculate the composition of the gas mixture in the process of plasma nitriding for different geometry chambers.

3. The use of special rigging in the form of a cylinder made of rolling steel ensures the constancy of the discharge power regardless of the number of parts inside the cylinder. This allows to organize the plasma nitriding process with the same flux density $\mathrm{N}_{2}{ }^{+}$, regardless of the number of simultaneously treated parts.

\section{References}

[1] Лахтин Ю.М, Рахштад А.Г., Термическая обработка в машиностроении (Heat treatment in mechanical engineering). - Москва: Машиностроение, 1980, с. 783. (In Russian).

[2] Берлин Е.В., Коваль Н.Н., Сейдман Л.А. Плазменная химико-термическая обработка поверхности стальных деталей (Plasma chemical and thermal treatment of the surface of steel parts). М.: Техносфера, 2012, с. 464. (In Russian).

[3] Чаттерджи-Фишер Р., Эйзелл Ф., пер. с нем./под ред. Супова А.В. Азотирование и карбонитрирование (Nitriding and carbonitriding) - Москва: «Металлургия», 1990, с. 280. (In Russian).

[4] David Pye. Practical Nitriding and Ferritic Nitrocarburizing, ASM International Park, Ohio, 2003.

[5] Sun Y., Bell T. Computer Prediction of Threshold Nitriding Potential Curves. Heat Treatment of Metals, №2, 1997, pp. 43-49.

[6] Лахтин Ю.М., Коган Я.Д., Булгач А.А. Расчёт влияния легирующих элементов на растворимость и диффузию азота в стали при азотировании в $\alpha$ и $\varepsilon$-фазах (Calculation of the effect of alloying elements on the solubility and diffusion of nitrogen in steel during nitriding in $\alpha$ and $\varepsilon$ phases), Труды московского автомобильно-дорожного института, Вып 174, 1979, с. 42-59. (In Russian).

[7] Лахтин Ю.М., Коган Я.Д., Булгач А.А. Расчёт влияния легирующих элементов на растворимость и диффузию азота в стали при азотировании в $\alpha$ и $\varepsilon$-фазах (Calculation of the effect of alloying elements on the solubility and diffusion of nitrogen in steel during nitriding in $\alpha$ and $\varepsilon$ phases), Труды московского автомобильно-дорожного института, Вып 174, 1979, с. 42-59. (In Russian).

[8] Моисеенко А.Н. Кинетика поглощения азота в процессах ионного азотирования (Тhe kinetics of nitrogen absorption in the processes of ion nitriding) Конференция, Книга 2, Современные методы и технологии создания материалов. - Минск: ФТИ НАН Беларуси, 2017, c. 190-198.(In Russian).

[9] Ionitech Ltd. Products. [online] [2018]. Available at: http://www.ionitech.com/products/coldwall-equipment.html.

[10]ФТИ НАН Беларуси. Упрочняющая ионная химико-термическая обработка (The PhysicalTechnical Institute of the National Academy of Sciences state scientific institution. Strengthening ionic chemical-thermal treatment). (In Russian) [online] [2018]. Available at: http://phti.by/product/Hardening-ion-chemical-heat-treatment.

[11]Plasma Nitriding Equipment For South America. [online] [27.04.2014]. Available at: https://www.secowarwick.com/en/news/plasma-nitriding-equipment-for-south-america/. 
[12] PVA Industrial Vacuum Systems GmbH. PulsPlasma® Nitriding / Oxidation. [online] [2018]. Available at: http://www.plateg.com/willkommen-eng.html.

[13]ELTRO GB Ltd. Nitriding Plants. [online] [2018]. Available at: http://www.eltropuls.de/en/products/plant-engineering/nitriding.

[14]RÜBIG Industrial Furnaces. Nitriding and Coating Systems. [online] [2017]. Available at: https://www.rubig.com/fileadmin/user_upload/AT/Downloads/AT_Folder_Anlagentechnik_A4_E N_20170321_Einzelseiten.pdf.

[15]Энгель А., Штенбек М. Физика и техника электрического разряда в газах (Physics and Technology of Electric Discharge in Gases), т. 2, ОНТИ-НКТП, 1936, с. 384(In Russian).

[16] Босяков М.Н., Козлов А.А. Энергетические параметры процессов ионного азотирования на промышленном оборудовании (The energy parameters of the processes of ion nitriding on industrial equipment) / Доклады БГУИР, 2013, № 3(73), c. 76-82. (In Russian).

[17] Edenhofer B. Fortschritte in der Prozessregelung beim Plasmaaufkohlen und Plasmanitrieren (Advances in process control in plasma carburizing and plasma nitriding). HTM, 44, 1989, pp. 339-346. (In German).

[18]Босяков М.Н., Моисеенко А.Н. Выбор режима упрочняющей обработки на установках ионного-азотирования промышленного типа (The choice of the mode of strengthening treatment on the installations for ion-nitriding industrial type), Книга 2, Современные методы и технологии создания материалов. - Минск: ФТИ НАН Беларуси, 2016, с. 50-58. (In Russian).

[19] Исаченко В.П., Осипова В.А., Сукомел А.В.. Теплопередача (Heat transfer). М.:Энергоиздат, 1981. (In Russian). 